\title{
TORZÁLNÍ ARCHITEKTURA V HISTORICKÉM JÁDRU PLZNĚ NA PŘÍKLADU ŠPITÁLNÍHO KOSTELA SV. MÁŘÍ MAGDALENY
}

\author{
VERONIKA DUDKOVÁ - JIŘÍ ORNA - MARCELA WALDMANNOVÁ
}

\begin{abstract}
Abstrakt: Př́spěvek se zabývá problematikou omezených možností výzkumů a prezentace torzální architektury $v$ historických jádrech mést z pohledu památkáře a archeologa na konkrétním príkladu z Plzné. Vletech 2010-2014 byl v rámci předstihového archeologického výzkumu odkryt půdorys špitálního kostela sv. Mář́ Magdaleny. Výzkum byl prováděn v souvislosti s plánovanou stavbou nové budovy Západočeské galerie, jejiž návrh vzešel z architektonické soutěže. Hned prvá etapa výzkumu prokázala až nečekaně dobrýstav dochování zdiva kostelika (nejen základů, ale i původně nadzemní části-po soklovou řmsu). Vzhledem $k$ tomu, že torzo sakrálni stavby se nacházelo mimo městskou památkovou rezervaci, byla cesta kjeho zachováni velmi složitá. Součástí př́spěvku je také shrnutí současného stavu poznání této sakrálni stavby.
\end{abstract}

Klí́čová slova: Plzeñ - středověk - špitál-kostel-kulturní památka.

\section{Ruins of Architecture in the Historical Centre of Plzeň on the Example of the Hospital Church of St. Mary Magdalene}

\begin{abstract}
This paper demonstrates the limited possibilities of research and presentation of ruins of architecture in historical centres of cities from the perspective of heritage experts and archaeologists, on a concrete example from Plzeñ. Preliminary archaeological research conducted in 2010-2014 uncovered the ground plan of the Hospital Church of St. Mary Magdalene. The research took place in connection with the planned construction of the new building of the West Bohemia Gallery, the design for which was the product of a tender. The first stage of the research showed unusually good repair of the church masonry (not only the foundations but also the original above-ground structure of the base ledge). As the ruin of the religious construction is located outside the urban conservation area, the journey to its preservation was rather complicated. Among other things, the article sums up the current state of knowledge about the building.
\end{abstract}

Key words: Plzeñ - Middle Ages - hospital-church-cultural monument.

\section{Úvod}

Pozůstatky špitálního kostela sv. Máří Magdaleny v Plzni, které byly částečně prozkoumány již v roce 1946, se znovu staly předmětem archeologického výzkumu v roce $2010 \mathrm{v}$ souvislosti se záměrem stavby nové budovy Západočeské galerie (dále ZČG). Předkládaný př́spěvek přináší jednak dílčí výsledky výzkumu pozůstatků kostela, a tedy částečné přehodnocení závěrů výzkumu z poloviny 20 . století, a pak také shrnutí událostí, které se ve vztahu k této významné památce torzálního charakteru v souvislosti se záměrem výstavby nové ZČG udály.

Volná plocha „U Zvonu“ určená ke stavbě nové budovy ZČG se nachází v historickém centru Plzně. Je vymezena ulicemi Pražskou na severovýchodě, U Zvonu na jihovýchodě a ulicí Křižíkovy sady na západě (obr. 1). Předmětná plocha je momentálně provizorně upravena na park. Vznikla demolicí činžovního domu v roce 2002, čímž došlo k rozpadu urbanistické struktury, a tak návrat zástavby $\mathrm{v}$ obdobné hmotě byl od počátku považován za nutnost. Na stavbu nové budovy ZČG byla Plzeňským krajem dne 29. ř́jna 2009 vyhlášena veřejná architektonická soutěž. Ulice Křižíkovy sady tvoří východní hranici Městské památkové rezervace Plzeň (dále MPR), Křižíkovy sady jako takové jsou součástí nemovité kulturní památky Okružní městské sady. Jelikož nemá MPR ochranné pásmo, mohla být předmětná plocha v době zadávání soutěže posuzována z hlediska zákona č. 20/1987 Sb., o státní památkové péči (dle odstavce 1 §14), pouze jako prostředí nemovité kulturní památky Okružní městské sady. V zadávacích materiálech architektonické soutěže měli účastníci k dispozici kompletní dokumentaci archeologického výzkumu kostela sv. Máří Magdaleny z roku 1946; mezi limity a omezeními řešení prostoru bylo o reliktech kostela sv. Máří Magdaleny uvedeno, že jeho zbytky nebrání zastavění, avšak bylo by žádoucí navrhnout jejich prezentaci v interiéru nebo parteru novostavby. Zvítězil návrh 


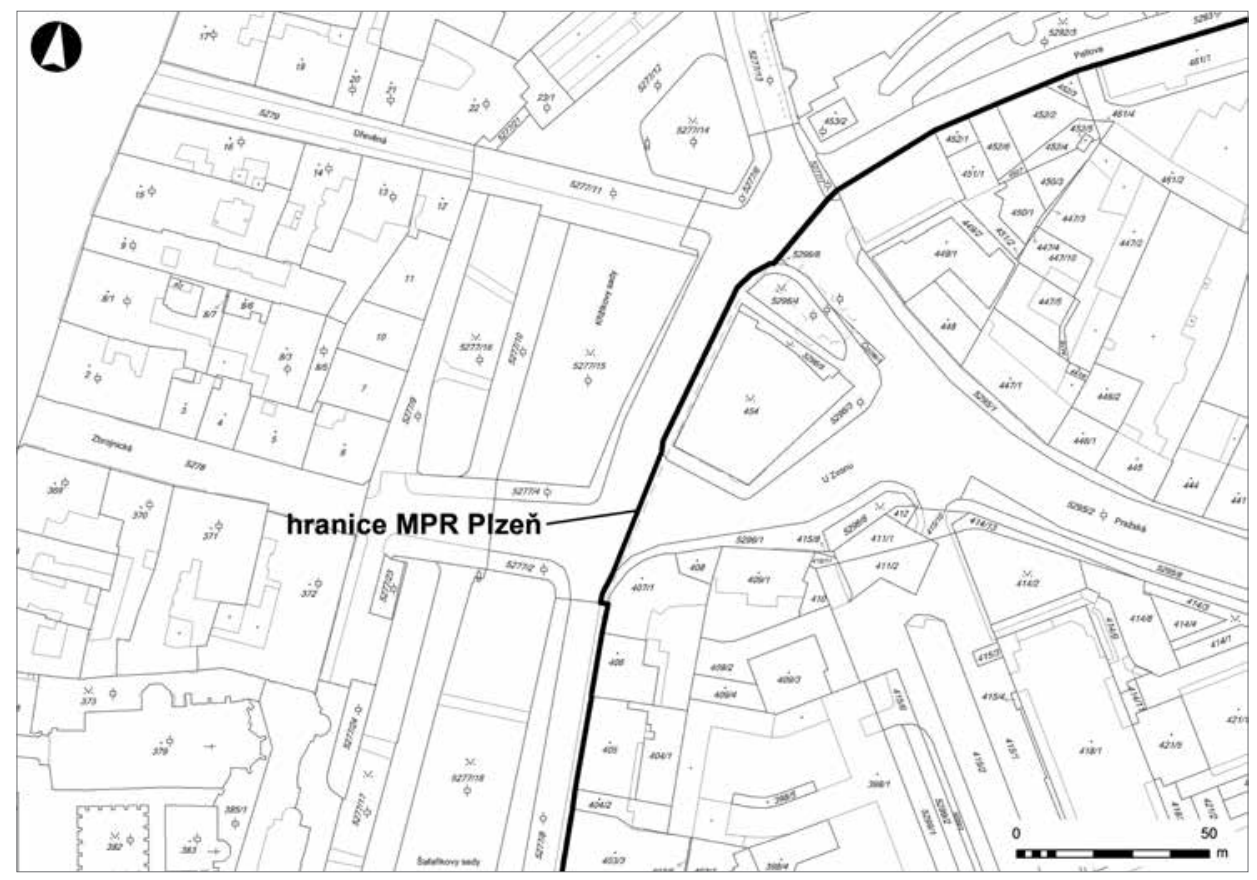

Obr. 1. Plzeň, lokalita „U Zvonu“, výřez z katastrální mapy s vyznačením hranice Městské památkové rezervace Plzeň. Polohopisný podklad WMS KN ® ČÚZK, http://services.cuzk.cz/wms/wms.asp, Souřadnicový systém S-JTSK Krovak East North, upravila Ž. Sedláková.

Abb. 1. Pilsen, Fundstelle „U Zvonu“ (,zur Glocke“), Katasterkartenausschnitt mit eingezeichneter Grenze des Städtischen Denkmalschutzgebiets von Pilsen. Lageplanvorlage WMS KN (C) ČUZK (Tschechisches Amt für Landesvermessung und Kataster), http:// services.cuzk.cz/wms/wms.asp, Koordinatensystem S-JTSK Krovak East North. Erstellt von Ž. Sedláková.

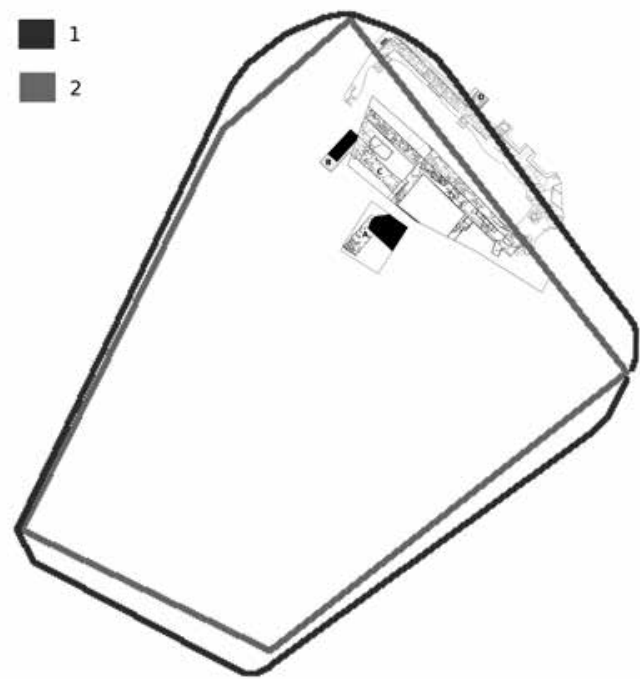

Obr. 2. Plzeň, kostel sv. Máří Magdaleny. Vyznačení polohy. 1 - hranice dotčeného pozemku, 2 - průběh obvodové stěny nové budovy Západočeské galerie v Plzni.

Abb. 2. Pilsen, Maria-Magdalenenkirche. Kennzeichnung der Lage. 1 - Grenze des betroffenen Grundstücks, 2 - Verlauf der Außenmauern des neuen Gebäudes der Westböhmischen Galerie in Pilsen. autorského týmu akad. arch. Ladislava Kuby a Ing. M. A Tomáše Pilaře (Kuba \& Pilař architekti s.r.o.), který podle názoru poroty nejkomplexněji splnil závazná kritéria soutěže; pozitivně byl návrh hodnocen i památkáři (http://www.zpc-galerie.cz/cs/vitezny-navrh-na-reseni-nove-budovy-zapadoceske-galerie-v-plzni-175). S relikty kostela návrh vůbec nepracuje, respektive navržená budova se jim půdorysně vyhýbá. Nepočítá se $\mathrm{s}$ žádnou prezentací pozůstatků kostela, ani jeho připomenutím, byt' např. pouze $\mathrm{v}$ půdorysné stopě.

S nutností provedení záchranného archeologického výzkumu $\mathrm{v}$ dostatečném předstihu před zahájením výstavby nové budovy ZČG počítal jak majitel pozemků (statutární město Plzeň), tak investor stavby (Plzeňský kraj). Prvé jednání nad odkrytými relikty kostela se konalo počátkem záŕí 2010 . Na jednání byli př́ítomní seznámeni s faktem, že pozůstatky kostela jsou dochovány v mnohem lepším stavu, než se očekávalo, a kolidují s navrženým založením nové budovy ZČG. Kolize 
se projevila jak polohopisně, tak výškopisně. Ukázalo se, že severní stěna novostavby prochází přibližně středem kostela a podélně ho tak dělí na jižní (resp. jihozápadní) část, která se ocitá uvnitř ZČG, a severní (severovýchodní) část kostela, která zůstává vně, pod chodníkem (obr. 2). Obvodová stěna budoucí galerie je opřena o samostatné piloty, které prochází podélnou osou kostela. Jejich umístění však lze ovlivnit - budou vrtány mimo zdivo kostela a po provedení záchranného archeologického výzkumu je jejich realizace možná. Výškopisná kolize však spočívala $\mathrm{v}$ tom, že oproti očekávání ${ }^{1}$ se koruna dochovaného zdiva (nejen základů, ale i původně nadzemní části zdiva - až po soklovou římsu) nacházela již v hloubce $0,2-0,3 \mathrm{~m}$ pod stávající úrovní terénu. Tento nečekaný výškový rozdíl kolidoval s navrženým způsobem založení novostavby, která má být v celém svém základu izolována, nebot’ se navíc nachází v zátopové oblasti.

Nastala komplikovaná a dlouhá jednání o tom, jak uchránit relikty stavby vysokého historického významu a stavu dochování ze 14. století před nevratným destruktivním zásahem při realizaci moderní architektury na počátku 21. století, v době značných technických možností.

\section{Kostel sv. Máří Magdaleny - jeho stavební podoba v písemných a obrazových pramenech}

V roce 1320 vznikl díky donaci bohatého plzeňského měšt’ana a radního Konráda z Dobřan špitál, situovaný na východ od městských hradeb, na předměstí, které bylo podle této insti-

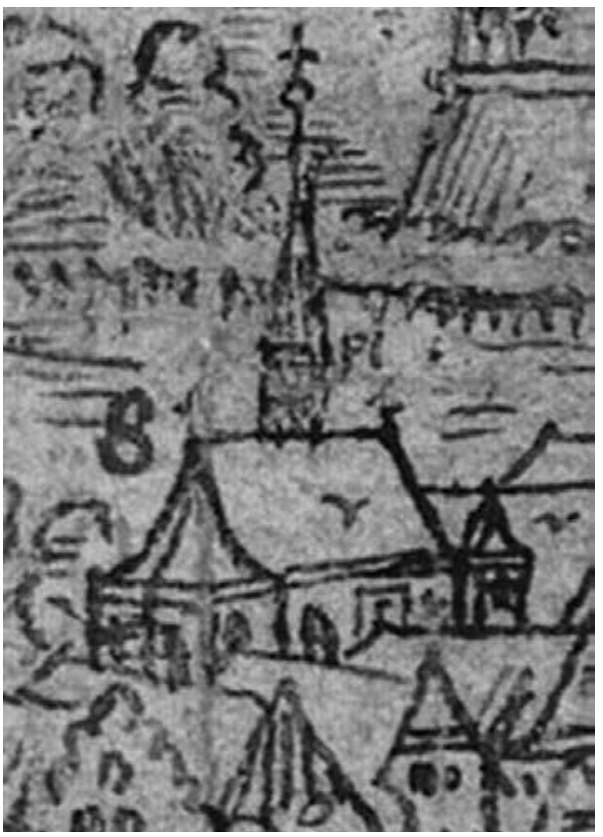

Obr. 3. Jan Willenberg, Velký pohled na Plzeň (výřez), 1602. Strahovská knihovna, sign. DT I. 30/II.

Abb. 3. Jan Willenberg, Großansicht von Pilsen (Ausschnitt), 1602. Strahover Bibliothek, Sign. DT I. 30/II. tuce ve středověku nazýváno jako Špitálské (suburbium hospitalense, preurbium circa hospitale) nebo jako předměstí před Pražskou branou (Prager Thor Vorstadt; podrobnější rozbor data vzniku Karlová 2008, 148-149). O rok později Přibislav, pražský světicí biskup, vysvětil špitální kapli sv. Máří Magdaleny a ustanovil, aby tato sakrální stavba příslušela pod pravomoc farního kostela (Strnad 1891, 10).

V opise se dochovala listina ze 17. srpna 1331, v níž král Jan Lucemburský uvádí, že Konrád z Dobřan nechal vystavět ,kapli pěknou z kamene" ve špitále sv. Máří Magdaleny (Strnad 1891, 25-26).

Z období po ukončení husitských válek směřuje na stavební činnost $\mathrm{v}$ areálu špitálu celá řada odkazů, prŕímo kostela se však týkají pouze tři. V roce 1495 Důra Kř́̌žová odkázala pět kop „na špitál ksv. Mař́ Majdaleně, když budú kuor dělati“" (Strnad 1905, 354). Roku 1501 Argella z Waldova ve své závěti do špitálu věnovala celých dvacet zlatých, a to výslovně na opravu kostela (Strnad 1905, 421). Osmého února 1503 poukázala na opravu kostela půltřetí kopy Anna Šafránková z Pautnova (Strnad 1905, 448).

První známé vyobrazení kostela sv. Máŕí Magdaleny je zachyceno na kresbě Jana Willenberga Velký pohled na Plzeň z roku 1602 (obr. 3). Z kostela je zde vidět pouze jeho horní část, tedy vrcholy oblouků oken a střecha se sanktusníkem. Pro případné barevné doplnění dřevořezu Willenberg uváděl poznámky o barvě střešní krytiny (Mergl 1995, 11). U špitálního kostela je

1 Geofyzikálním průzkumem (geoelektrické odporové měření, Křivánek 2010) se do hloubky 1 m neprokázaly výraznější relikty zdiva či kamenné destrukce. 

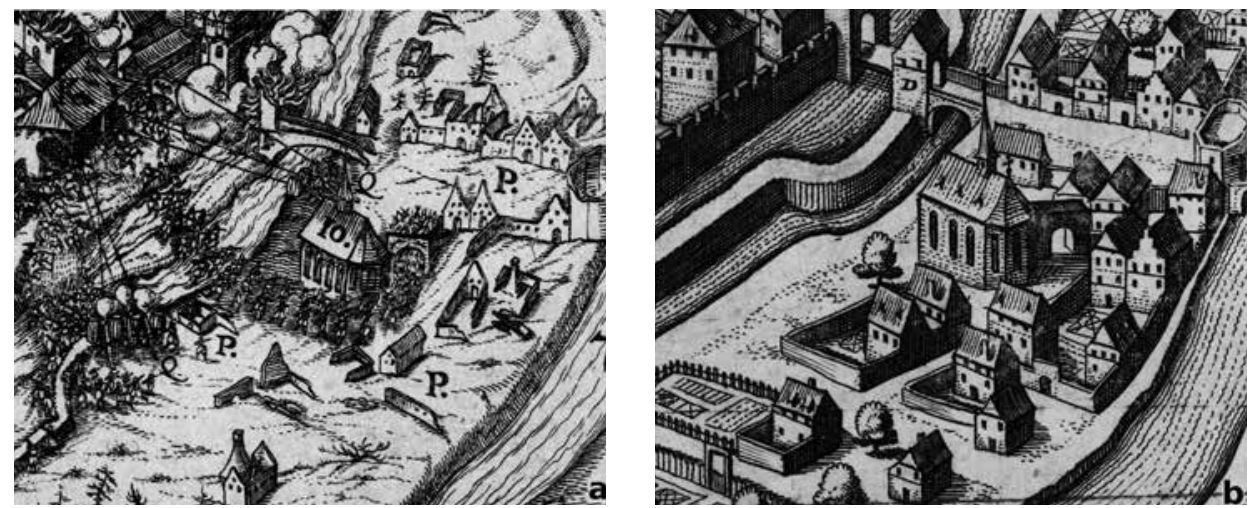

Obr. 4. Historické veduty města Plzně. a - Johann Hauer, Dobytí Plzně Mansfeldem roku 1618 (výřez), kolem 1620. Západočeské muzeum v Plzni, inv. č. G 141; b - Matthäus Merian st., Pohled na Plzeň (výřez), před 1650. Západočeské muzeum v Plzni, inv. č. G 138. Abb. 4. Historische Stadtansicht von Pilsen. a - Johann Hauer, Einnahme von Pilsen durch Mansfeld im Jahr 1618 (Ausschnitt), um 1620. Westböhmisches Museum in Pilsen, Inv.-Nr. G 141; b - Matthäus Merian d.Ä., Blick auf Pilsen (Ausschnitt), vor 1650. Westböhmisches Museum in Pilsen, Inv.-Nr. G 138.

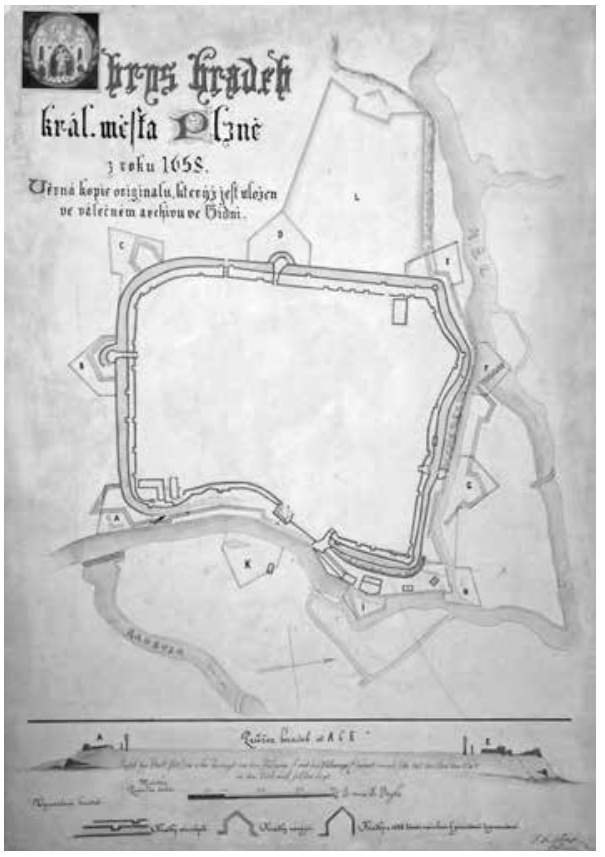

Obr. 5. Kopie plánu opevnění královského krajského města Plzně a projektu jeho úprav $z$ roku 1658 , půdorys a řez, autor $F$. $X$. Franc, 1. 7. 1895. Západočeské muzeum v Plzni, inv. č. MP 143. Abb. 5. Kopie des Plans der Befestigung der königlichen Kreisstadt Pilsen mit Änderungsentwurf aus dem Jahr 1658, Grundriss und Schnitt, angefertigt von F. X. Franc, 1.7.1895. Westböhmisches Museum in Pilsen, Inv.-Nr. MP 143.

délka sakrální stavby dosahuje 14 vídeňských sáhů, tedy 25 metrů.

Na obraze Maxmiliana Seeblummera Pohled na Plzeň v pozadí obrazu sv. Václava z roku 1672 je kostel sv. Máří Magdaleny vyobrazen jako osaměle stojící stavba (obr. 6). 


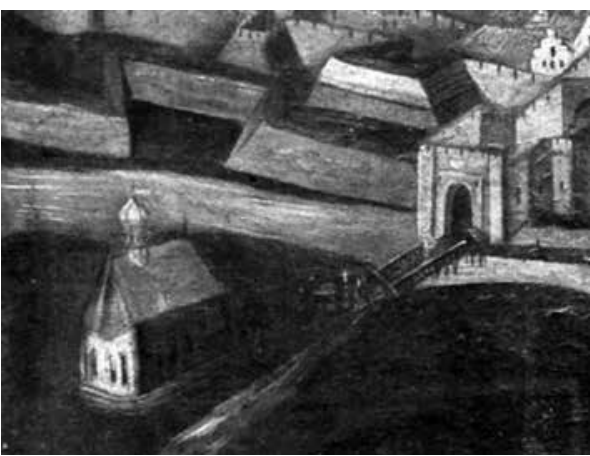

Obr. 6. Maxmilian Seeblummer, Pohled na Plzeň v pozadí obrazu sv. Václava (výřez), 1672. Západočeské muzeum v Plzni, inv. č. G 182.

Abb. 6. Maxmilian Seeblummer, Blick auf Pilsen im Hintergrund eines Gemäldes mit HI. Wenzel (Ausschnitt), 1672. Westböhmisches Museum in Pilsen, Inv.-Nr. G 182.

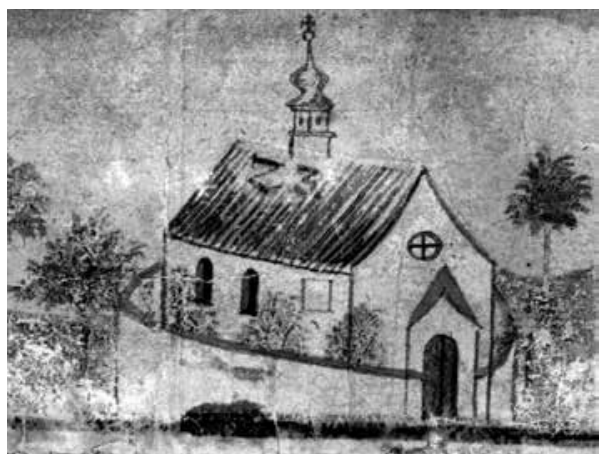

Obr. 7. Neznámý autor, Plzeň od východu (výřez), po 1735. Západočeské muzeum v Plzni, inv. č. G 580.

Abb. 7. Unbekannter Künstler, Pilsen von Osten (Ausschnitt) nach 1735. Westböhmisches Museum in Pilsen, Inv.-Nr. G 580.

Na vyobrazeních Plzně od Friedricha Bernharda Wernera z let $1726-1729$ a po roce 1735 (Mergl 1995, obr. 27, 28) je kostel sv. Máří Magdaleny vyobrazen velmi nepřesně, chybně je však tímto autorem vyobrazena i celá řada dalších významných plzeňských staveb té doby (Historický atlas měst 2009, XVI).

Na akvarelu ukazujícím Plzeň od východu z doby po roce 1735 je zachycena obvodová zed’ hřbitova (obr. 7).

Poslední vyobrazení kostela ukazuje plán na dostavbu barokní kostnice u této sakrální stavby z 22. července 1779 (obr. 8) a půdorysný plán královského krajského města Plzně z roku 1781 (obr. 9).

Roku 1783 byl kostel sv. Máří Magdaleny zrušen, o rok později i hřbitov (Martinovský a kol. 2004, 108).

\section{Archeologický výzkum v roce 1946}

Při jednom ze spojeneckých náletů na Plzeň v prosinci 1944 byl zasažen klasicistní dům postavený na konci 18. století na místě zrušeného kostela sv. Máří Magdaleny. Při odklízení trosek na jaře roku 1946 se ukázalo, že zděné konstrukce této sakrální stavby byly součástí demolovaného domu. $\mathrm{V}$ té době byly relikty domu ubourány na úroveň terénu tehdejší ulice. Jedna z podélných zdí kostela byla dochována po výběhy kleneb, sondáží měl být ověřen průběh dalších konstrukcí kostela (Mencl 1946). Výkopové práce archeologického výzkumu zajištoval úředník městského stavebního úřadu Ing. Ladislav Fiala, registrace nálezů se ujal plzeňský historik Ladislav Lábek (Mencl 1946). Supervizi nad výzkumem převzal doc. Dr. Václav Mencl ze Státního archeologického ústavu v Praze.

V průběhu výzkumu bylo odkryto obvodové zdivo celé stavby s pětibokým závěrem, opěrné pilíře, vnější ozdobná profilovaná obvodová římsa, spodní části přípor žeber, zbytky kleneb a okenních kružeb, zachovalo se i sedile a dubové trámy nesoucí kruchtu (Lábek 1947, 3-4).

Výše uvedený popis L. Lábka doplňuje velmi kvalitní kresebná dokumentace od architekta L. Fialy. Ten zachytil půdorys kostela a jeho severní, jižní a západní stěnu. Dokumentaci opatřil i niveletou, pracoval s relativním výškopisem, kde $0=304,19 \mathrm{~m} \mathrm{n}$. m. Pečlivost dokumentace podtrhuje zachycení rozsahu dochování historických omítek.

Archeologický výzkum v roce 1946 podle dobových zvyklostí rezignoval na sledování stratigrafických vztahů a soustředil se především na odkrytí konstrukcí špitálního kostela sv. Máří Magdaleny. Závěry, které vzešly ze zjištění tohoto výzkumu, přinesli všichni, kdo se 


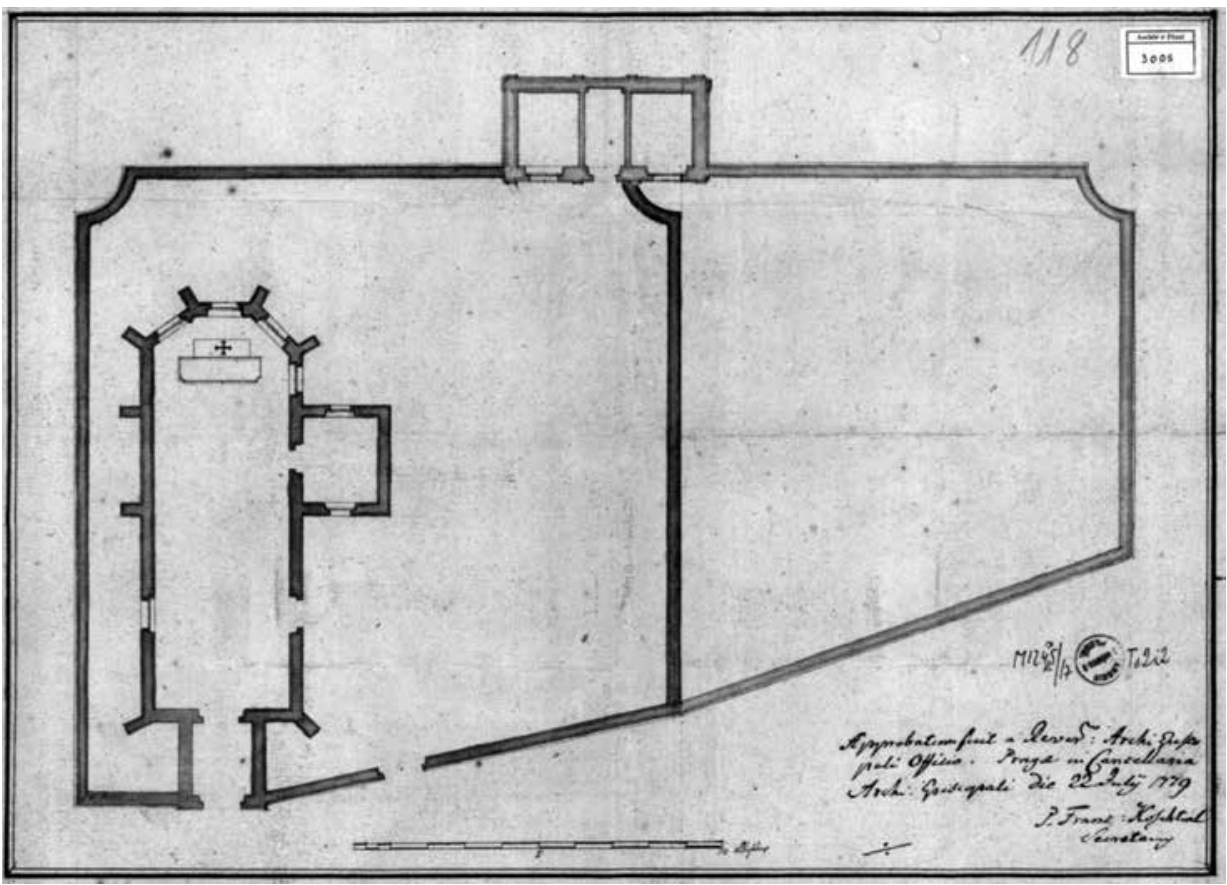

Obr. 8. Plán na dostavbu barokní kostnice u kostela sv. Máří Magdaleny (výřez), 22. července 1779. Archiv města Plzně, Sbírka map a plánů, inv. č. M 1254/17.

Abb. 8. Ausbauplan für das barocke Beinhaus an der Maria-Magdalenenkirche (Ausschnitt), 22. Juli 1779. Archiv der Stadt Pilsen, Karten- und Plansammlung, Inv.-Nr. M 1254/17.

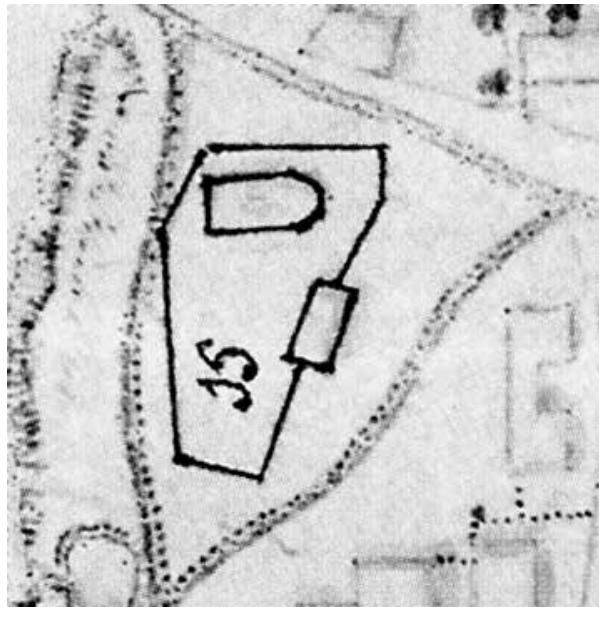

Obr. 9. Půdorysný plán královského krajského města Plzně, 1781 (výřez). Západočeské muzeum v Plzni, inv. č. MP 57.

Abb. 9. Grundrissplan der königlichen Kreisstadt Pilsen, 1781 (Ausschnitt). Westböhmisches Museum in Pilsen, Inv.-Nr. MP 57. na něm podíleli. V. Mencl se kromě popisu odkrytého kostela omezil na sdělení, že kostel byl na počátku husitských válek - $\mathrm{v}$ rámci přípravy předměstí realizované Janem Žižkou - „úmyslně celý zbořen až po povrch země a potom znovu na starém půdorysu postaven" (Mencl 1961, 31). To uvádí i L. Lábek (1947, 3), který však poskytl i řadu dalších informací. Přestavbu a rozšíření kostela směrem k městu zasadil do období renesance, konkrétně do druhé poloviny 16 . století, kdy měla být zvýšena úroveň podlahy kostela o metr (Lábek 1947, 4). Úrovně podlah řešil i L. Fiala ve své dokumentaci, v níž vyznačil úroveň podlah z roku 1332 a doby pozdně gotické (obr. 10).

Architekt Fiala se neomezil na prostou dokumentaci výzkumem odkrytých konstrukcí špitální sakrální stavby, snažil se i o jejich slohové zařazení (obr. 11). Pro lepší představu pak vytvořil rekonstrukci podob kostela sv. Máří Magdaleny (obr. 12). Starší fáze, Fialou označovaná jako raně gotická, odpovídá publikovanému popisu od V. Mencla $(1961,31)$. Podle nich se v nejstarší podobě špitálního kostela vítězný oblouk otevíral do větší prostory - 
lodi této sakrální stavby. Při rekonstrukci předpokládané pozdně gotické podoby kostela zř̌ejmě architekt L. Fiala využil půdorys této stavby, zachycený na již zmíněném plánu na dostavbu barokní kostnice z 22. července 1779 (obr. 8).

\section{Archeologické výzkumy v letech 2010-2014}

Záchranné archeologické výzkumy realizované v letech 2010 až 2014 reagovaly na záměr výstavby nové budovy Západočeské galerie v Plzni. První etapa výzkumu proběhla v letech 2010 a 2011 a jejím hlavním úkolem bylo upřesnění stavu té části kostela sv. Máří Magdaleny, která se měla nacházet v interiéru plánované stavby. Po selhání nedestruktivních metod (Křivánek 2010; Špaček 2010) proto ve druhé polovině roku 2010 proběhl plošný odkryv jihozápadní části kostela. Zachycené zdivo mělo být prozkoumáno až na úroveň základové spáry. To se však v plném rozsahu nepodařilo, zčásti to zapř́íčinilo omezení rozvody funkčních inženýrských sítí, hlavně však přerušení výzkumu kvůli odkladu výstavby nové budovy galerie na neurčito.

$\mathrm{V}$ roce 2012 byla odkryta převážná většina zbylého rozsahu kostela. Při tomto výzkumu vyvolaném plánovanou revitalizací okolí zatím nepostavené nové budovy Západočeské galerie v Plzni postačovalo odkrytí koruny zdiva kostela sv. Máří Magdaleny.

Uvedené výzkumy lze označit také jako určitou revizi odkryvu kostela v roce 1946. Je možné konstatovat, že jediným výrazným narušením konstrukcí kostela od poválečné prospekce byl výkop pro pokládku kabelovodu ze 70 . let 20. století, který protnul kostel ve směru severozápad-jihovýchod a definitivně zničil polygonální závěr a vstup v západním průčelí.

Zjištění výzkumu naznačila nutnost korekce některých závěrů vzešlých ze zkoumání špitálního kostela v roce 1946. Sakrální stavbu vysvěcenou v roce 1321 tvořil presbytáŕ o délce necelých 11 metrů s polygonálním závěrem. Podle nejnovějších zjištění nebyla budova kostela v nejstarší fázi opatřena vnějším opěrným systémem, ale stabilitu vnitřního klenutého prostoru umožňoval systém klenebních přípor, v koutech jednoduchých, při stěnách svazkových (Anderle 2015, 19). Další oporu sakrální stavbě poskytovala budova špitálu (obr. 13:1). Společnou výstavbu svatyně a budovy špitálu u její jižní stěny dokládá propojení jejich základových partií (obr. 14).

Teorii architekta L. Fialy, že se v této fázi vítězný oblouk otevíral do větší prostory - lodi sakrální stavby, je třeba odmítnout. Tato prostora je v novější literatuře považována za pravděpodobnou budovu špitálu (Hajšman-Sokol 2010, 18; Široký-Wasková-Postránecká 2007, 18). Zděná budova špitálu však byla $\mathrm{v}$ tomto prostoru vystavěna až po husitských válkách (Dudková-Orna-Netolický 2014, 233).

Určitá negativa umístění špitálu na předměstí se naplno projevila za husitských válek. V té době mělo v roce 1419 dojít v rámci Žižkova opevňování Plzně a zajištování jeho předměstí ke zboření kostela sv. Máŕí Magdaleny „až po povrch země“ (Mencl 1961, 31). O těchto aktivitách se zmiňuje i další literatura, podle které při přebudování města na pevnost byly pobořeny domy na předměstí a oba kláštery (Bělohlávek a kol. 1965, 77). ${ }^{2}$ Tuto informaci poněkud devalvuje úvaha, že kláštery měly zpevňovat kritická místa hradeb (Bělohlávek a kol. 1965, 37). V areálu dominikánského kláštera sice $\mathrm{v}$ roce 1419 nastalo boření jeho zástavby, to však mělo především důvody ideové (Strnad 1896, 17). Tyto důvody však lze u kostela sv. Máŕí Magdaleny vyloučit, ještě před husitskými válkami byli v souvislosti s návratem radikálního husitského kazatele Václava Korandy do Plzně němečtí rytíríi zbaveni správy špitálu a ten byl svěřen laickým kněžím (Strnad 1896, 16). O poboření objektů na předměstí se zmiňuje (bohužel bez udání zdroje této informace) i nejnovější literatura nastiňující dějiny Plzně (Bystrický 2014, 194).

Hilarius Litoměřický při popisu obléhání Plzně Janem Žižkou v roce 1421 uvádí, že sice nedosáhl úspěchu, ale odtáhl s neobyčejně bohatou kořistí pocházející z předměstí (Hejnic-Polívka 1987, 142), která husitská vojska obsadila při prvním útoku (Vavřinec z Březové 1979, 213).

2 M. Bělohlávek předpokládal zboření domů na předměstí také v roce $1470 \mathrm{v}$ období poděbradských válek. I tato představa byla zpochybněna (Wasková-Široký 2007, 95). 


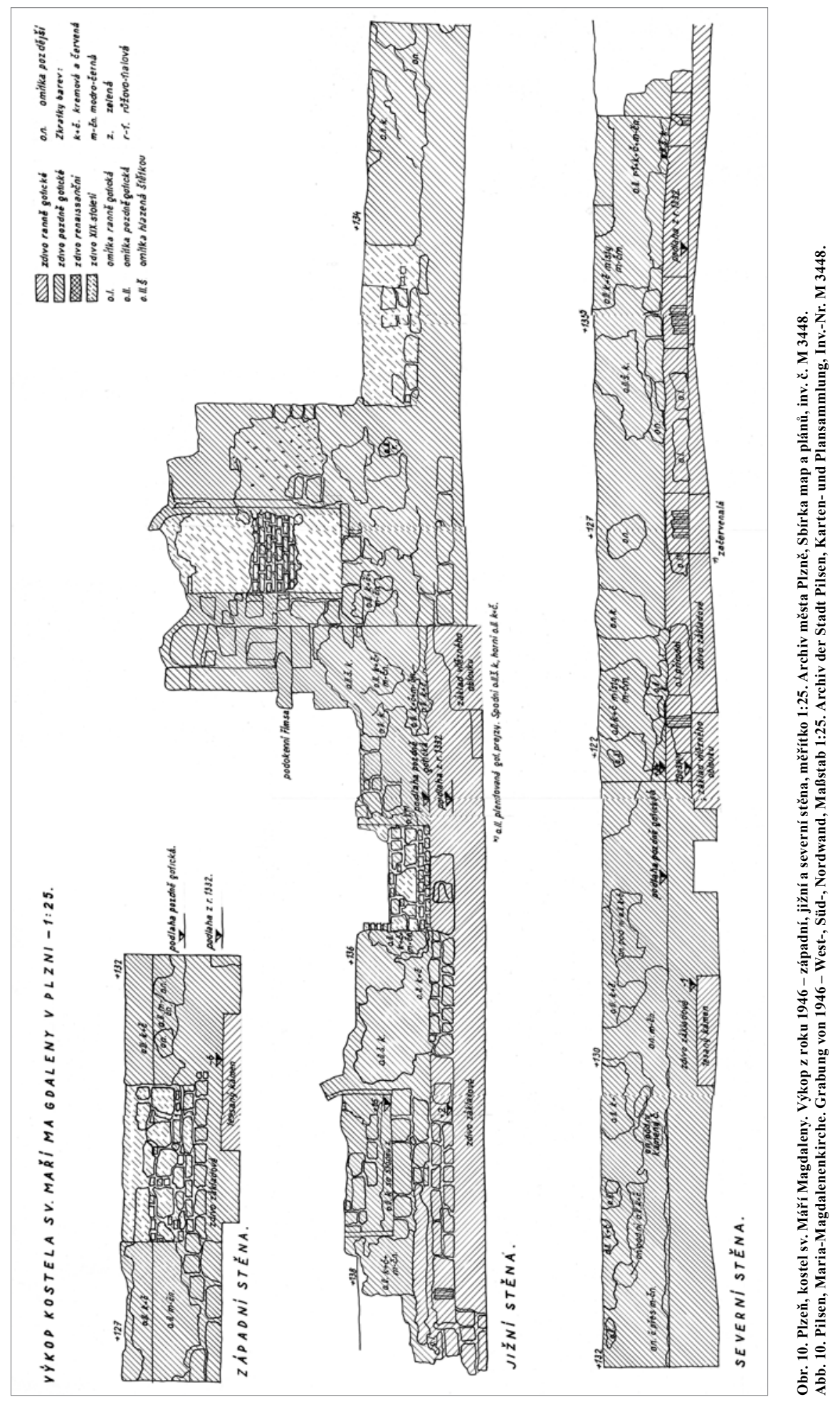




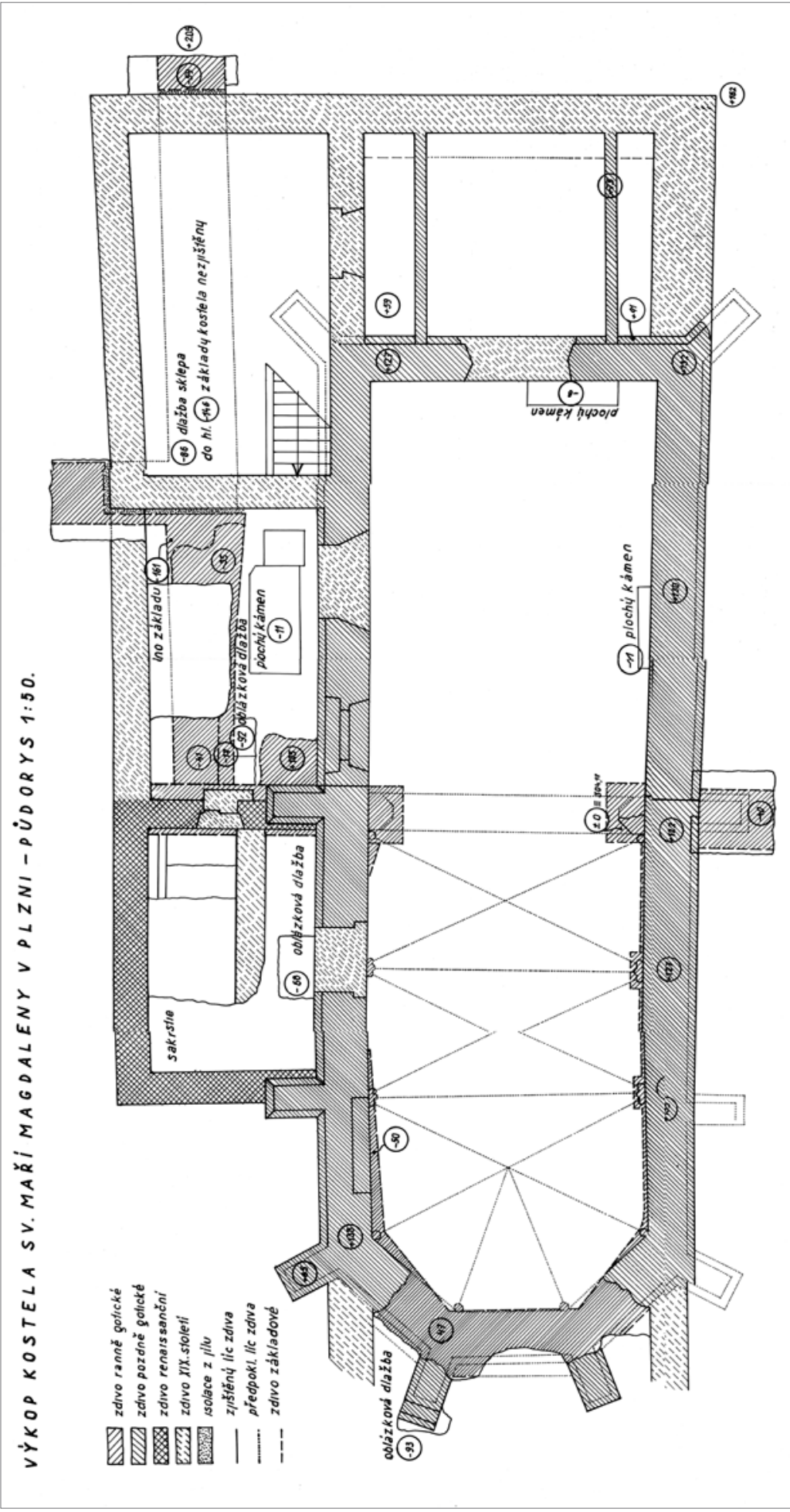

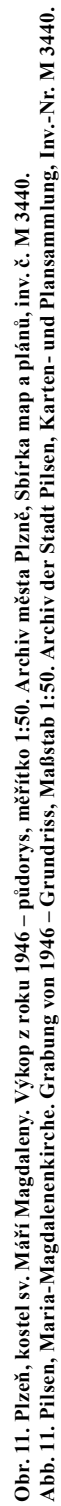




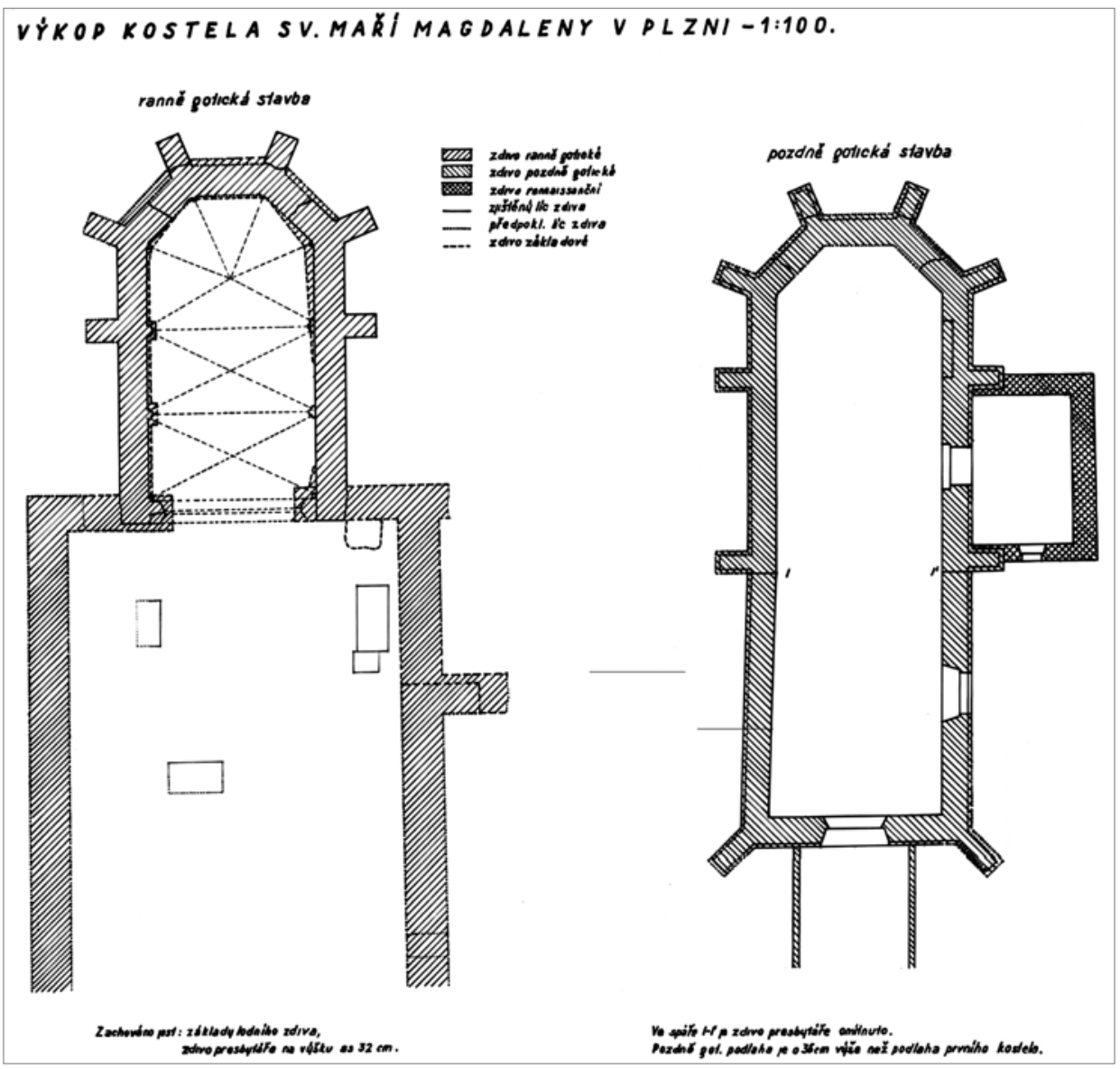

Obr. 12. Plzeň, kostel sv. Máří Magdaleny. Rekonstrukce stavebních fází kostela podle L. Fialy. Archiv města Plzně, inv. č. M 3442. Abb. 12. Pilsen, Maria-Magdalenenkirche. Rekonstruktion der Bauphasen der Kirche nach L. Fiala. Archiv der Stadt Pilsen, Inv.-Nr. M 3442 .

K dalšímu zplanýrování zástavby na předměstí mělo dojít v roce 1433 (Sokol 2014, 46). Ve druhé polovině tohoto roku východní předměstí obsadili husitští obléhatelé Plzně (Hejnic-Polívka 1987, 305).

Dokladem úpravy zástavby na předměstí v období husitských válek je svědectví Hilaria Litoměřického, podle kterého ještě $\mathrm{v}$ roce 1467 nebyly obnoveny měštany stržené předměstské sýpky a dvory i se stodolami (Hejnic-Polívka 1987, 376).

Při konstrukci aktivit na předměstích v průběhu husitských válek některými autory mohlo také dojít $\mathrm{k}$ aplikaci retrogresivní metody - praxe obvyklá v novověku byla přenesena na středověké poměry. $\mathrm{V}$ tomto př́ípadě máme i v Plzni doložený postup, který se běžně používal za tř̌icetileté války - velitel císařské posádky bránící Plzeň Felix Dornheim nechal 30. září 1618 preventivně spálit zástavbu na Pražském a Skvrňanském předměstí (Bělohlávek 1997, 11).

Přes výše uvedené rozpory je jisté, že špitální areál během husitských válek utrpěl mnohé škody. Keramické nádoby nalezené pod stavbou zničenou požárem (Dudková-Orna-Netolický 2014, 235) nasvědčují spíše náhlé katastrofě než intencionální likvidaci stavby. Archeologický ani stavebně historický průzkum nepřinesly žádné př́imé doklady Menclem i Lábkem zmiňovaného zboření sakrálního objektu v období husitských válek (Lábek 1947, 3; Mencl 1961, 31). 
Pokud by k němu opravdu došlo, znamenalo by to velké nesnáze pro fungování špitálu. Písemné prameny totiž uvádějí opravy kostela až v letech 1495-1503 a lze si jen velmi obtížně představit, že by špitál tak dlouho mohl fungovat bez svatyně. Po husitských válkách došlo k přesunu budovy špitálu z jižní strany kostela k jeho západní části, výše uvedená stavební činnost tedy může souviset s propojením alespoň částečně dokončené nové budovy špitálu s kostelem již zmiňovaným vítězným obloukem a odstraňováním napojení reliktů původní budovy. Tato změna se však zřejmě na podobě sakrální stavby výrazněji neprojevila (obr. 13:2). Úprava dispozice komplexu ovšem přinesla změnu, pro svatyni špitálu se místo označení kaple (capella) používá výraz kostel (ecclesia; Karlová 2008, 154, 155).

Prodloužení kostela směrem k městu, které L. Fiala klade do pozdní gotiky a L. Lábek do druhé poloviny 16. století, bezesporu souviselo se zánikem špitálu. Avšak k tomu pravděpodobně došlo až na počátku třicetileté války (Dudková-Orna-Netolický 2014, 234). Na Willenbergově vyobrazení kostela sv. Máří Magdaleny z roku 1602 se podle počtu oken zdá být zachycena tato stavba ve stejném rozsahu, jaký měla při svém vysvěcení v roce 1321. Na stěně kostela není viditelný žádný vnější opěrný systém. V této souvislosti je třeba zmínit, že stavebně historické průzkumy potvrdily věrnost Willenbergovy kresby u řady objektů, včetně počtu, polohy a proporcí oken a dalších architektonických detailů (Historický atlas 2009, XV).

Poněkud složitější je vyhodnocení zachycení kostela na vedutě Dobytí Plzně Mansfeldem. Předloha, z které vycházejí všechna další vyobrazení, se nedochovala (Mergl 1995, 13). Na vedu-

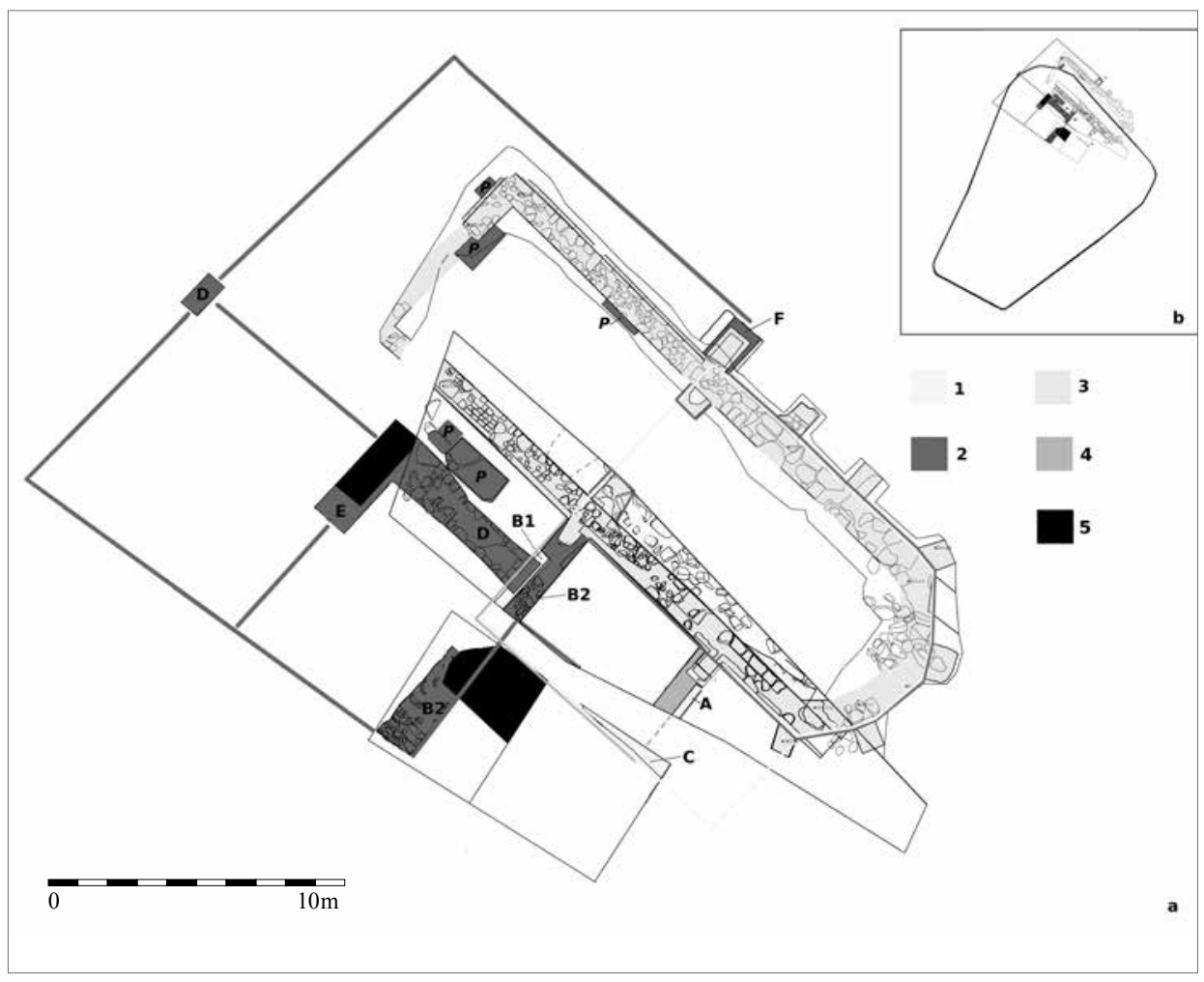

Obr. 13. Plzeň, kostel sv. Máří Magdaleny. Rekonstrukce stavebních fází kostela a budov špitálu. 1 - předhusitská fáze, 2 - pohusitská fáze, 3 - prodloužený kostel po třicetileté válce, 4 - sakristie, 5 - recentní konstrukce. Orientováno k severu. Autor V. Dudková. Abb. 13. Pilsen, Maria-Magdalenenkirche. Rekonstruktion der Bauphasen der Kirche und der Spitalgebäude. 1 - vorhussitische Phase, 2 - nachhussitische Phase, 3 - verlängerte Kirche nach dem Dreißigjährigen Krieg, 4 - Sakristei, 5 - rezente Konstruktion. Nördliche Orientierung. Erstellt von V. Dudková. 
tách je v zachycení města řada nepřesností, zmíněna byla již zrcadlově obrácená poloha kostela sv. Máří Magdaleny v rámci špitálního areálu. Stavebně historické průzkumy prokázaly omezenou vypovídací hodnotu vyobrazených dominant města, s výjimkou staveb, které měly přímou vazbu na válečnou akci, jako příklad bývá uváděna dýmníková kuchyně františkánského kláštera (Historický atlas 2009, XVI). Přímou vazbu na válečnou akci, jak ostatně ukazuje tato veduta, měl také špitální kostel. Na stěně této stavby najdeme ve variantách veduty tři (4 exempláře) nebo čtyři ( 2 exempláře) okna. Také s ohledem na toto statistické vyhodnocení lze předpokládat, že zachycená sakrální stavba měla spíše menší počet oken, a tedy by stále šlo o rozsah daný od roku 1321. Na žádné z vedut nemá kostel vnější opěrný systém.

Po zániku špitálu začal být pozemek u kostela sv. Máŕí Magdaleny intenzivně využíván jako pohřební areál. To znamenalo poměrně výrazný nárůst terénu v tomto prostoru (zhruba o jeden metr), a to i v bezprostřredním okolí svatyně. Zánik špitálu přinesl změnu podoby sakrální stavby, byla prodloužena západním směrem (obr. 13: 3), jak dosvědčuje zřetelná spára mezi lodí a presbyteriem (Anderle 2015, 16). S uvedeným nárůstem terénu souvisela potřeba navýšení úrovně podlahy kostela. Po tomto navýšení zanikl dosavadní vnitřní opěrný systém a musel být vybudován systém vnější (obr. 13:3). Relativní datování realizace tohoto systému umožňuje výzkumem odkrytý hrob č. 3/502, narušený při výstavbě jednoho z opěráků (obr. 15, 16). Výšková úroveň i odkryté relikty rakve nasvědčují tomu, že k pohřbu došlo až po uvedeném výrazném navýšení terénu.

Důvodem rekonstrukce kostela mohlo být také jeho větší poškození při událostech třicetileté války. Západním směrem prodloužený kostel s vnějším opěrným systémem je prvně zachycen na plánu opevnění města a projektu jeho úprav z roku 1658. Délka sakrální stavby podle plánu dosahuje ca 30 pražských loktů, tedy necelých 18 metrů (skutečná délka je 20 metrů). Vzhledem k tomu, že $\mathrm{v}$ roce 1648 městská rada rozhodla o preventivním spálení zástavby předměstí kvůli obavě z vojsk švédského generála Königsmarka, k přestavbě kostela došlo zřejmě až po skončení třicetileté války. V té době už se zde pohřbívalo, při morové epidemii v roce 1648 zde bylo ukládáno minimálně deset zemřelých týdně (Hajšman-Sokol 2010, 16).

Přistavěná sakristie u kostela je prvně zachycena na plánu opevnění Johanna Christiana Ziznera z roku 1703 . K její výstavbě tedy muselo dojít mezi lety 1658 a 1703 . Archeologický výzkum prokázal, že při jejím budování byly druhotně využity základové partie starších stavebních konstrukcí náležejících předhusitské i pohusitské fázi budovy špitálu (obr. 13:4). Celková délka sakrální stavby podle tohoto plánu dosahuje 14 vídeňských sáhů, tedy 25 metrů.

Na plánu města od Friedricha Bernharda Wernera z let 1726-1729 ke kostelu přiléhá ohraničený pozemek (Mergl 1995, obr. 27). To by mohl být pohřební areál vymezený hřbitovní zdí. Poněkud nejasná orientace celého komplexu je jen další z výrazných chyb tohoto plánu (Historický atlas 2009, XVI). Obvodovou zed' hřbitova tak prokazatelně, byt' v poněkud stylizované formě, ukazuje až akvarel zhotovený po roce 1735 (obr. 7). Lepší představu o rozsahu hřbitova i podobě kostela sv. Máří Magdaleny lze získat z plánu na dostavbu barokní kostnice z 22. července 1779 (obr. 8) a na půdorysném plánu královského krajského města Plzně z roku 1781 (obr. 9).

\section{Řešení kolize reliktů kostela s vítězným projektem}

V počátcích řešení kolize novostavby s relikty kostela byla situace pro památkovou péči složitá z již uvedených důvodů - prostranství U Zvonu mohlo být dle památkového zákona posuzováno pouze jako prostředí kulturní památky Okružní městské sady - tedy čistě z hlediska pohledově se uplatňujících změn. Zejména z důvodu historické hodnoty, ale také samozrrejmě z důvodu aktuálního ohrožení stavební aktivitou, byl v nejbližší možné době (po geodetickém zaměření) podán návrh na prohlášení odhalených reliktů kostela za kulturní památku - konkrétně byl návrh Akademii věd ČR postoupen 17. 9. 2010. Navrhovaná ochrana se omezovala na obvodové zděné konstrukce kostela a sakristie. 
Mezitím probíhala jednání s projektanty, kteří nedokázali nalézt takové technické řešení, jež by plně relikty kostela respektovalo a zároveň ponechávalo návrh novostavby beze změn vnitřní dispozice, tedy v té podobě, $\mathrm{v}$ jaké návrh zvítězil v architektonické soutěži. Za ideální řešení z pohledu projektantů by bývalo bylo plošné ubourání určitých úseků stěn kostela o $0,9 \mathrm{~m}$ pod úroveň terénu, což bylo pro archeology a zástupce památkové péče absolutně nepřijatelné. Druhá (a dle architektů poslední možná) navržená varianta počítala s oddělením a vyjmutím části zdiva kostela (na dvou místech měl být proveden průraz zdiva $\mathrm{v}$ šířce $0,8-0,9 \mathrm{~cm}$ na celou jeho výšku až po základovou spáru) a provedením navržené izolace proti spodní vodě tak, aby se tato část stala součástí novostavby.

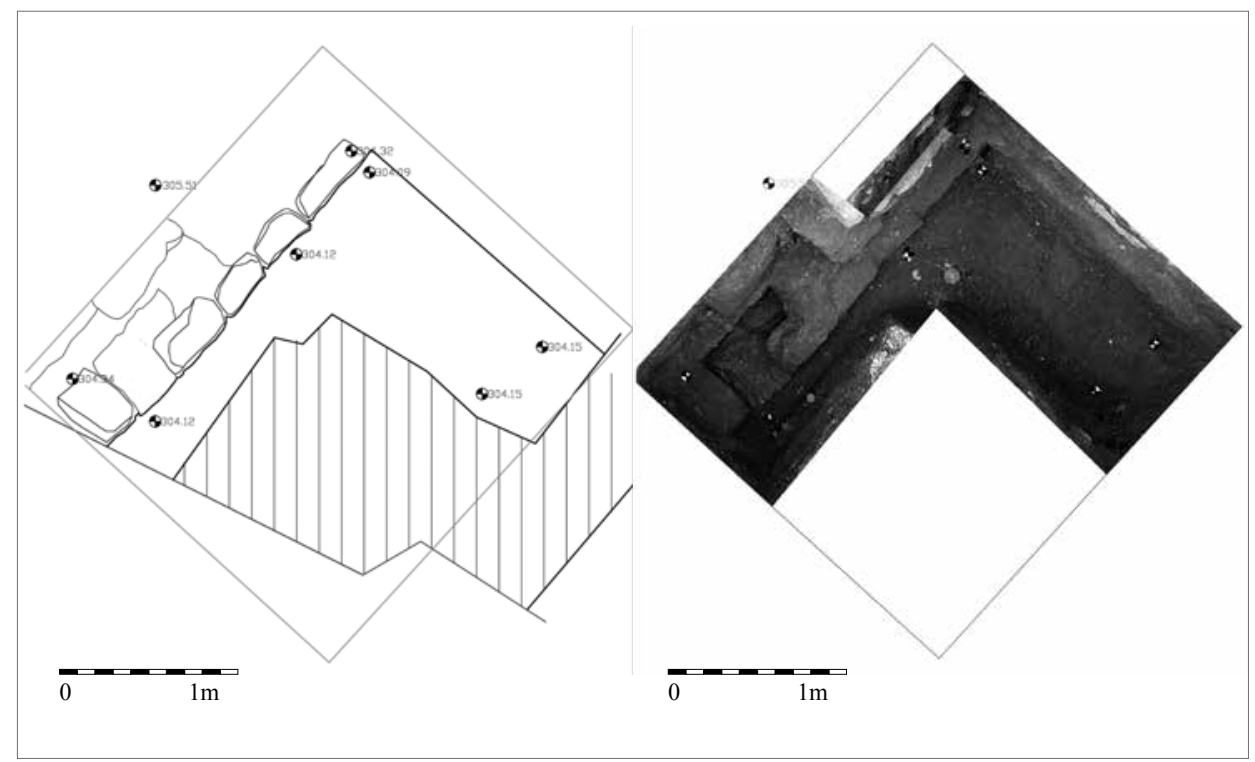

Obr. 14. Plzeň, kostel sv. Máří Magdaleny. Dokumentace konstrukce A. Orientováno k severu. Autor J. Koštial.

Abb. 14. Pilsen, Maria-Magdalenenkirche. Dokumentation von Konstruktion A. Nördliche Orientierung. Erstellt von J. Koštial.

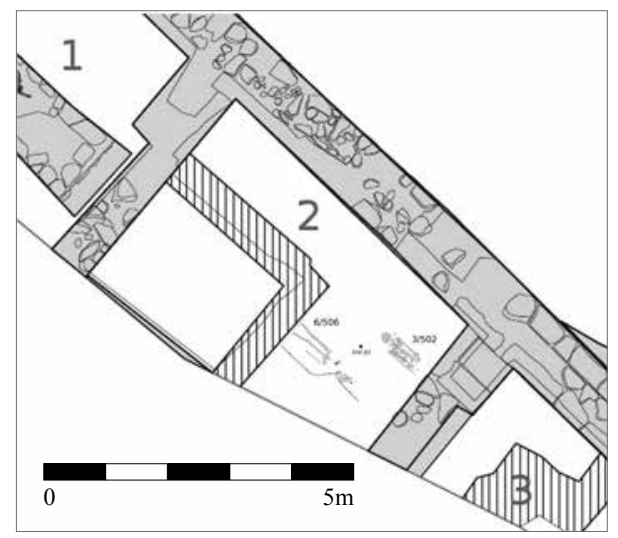

Obr. 15. Plzeň, kostel sv. Mář́ Magdaleny. Dokumentace hrobů $3 / 502$ a 6/506, sonda 2. Orientováno k severu. Autor O. Baier. Abb. 15. Pilsen, Maria-Magdalenenkirche. Dokumentation der Gräber 3/502 und 6/506, Sondierschnitt 2. Nördliche Orientierung. Erstellt von O. Baier.
Dne 7. 10. 2010 byla svolána odborná archeologická komise, která doporučila, aby byly rudimenty odkryté architektury v plné šíri konzervovány a zachovány.

Přesto byla na poradě Projektového týmu $\mathrm{k}$ výstavbě nové galerie v Plzni ze dne 14. 10. 2010 výše popsaná druhá varianta řešení všemi př́tomnými shledána akceptovatelnou, i když za dodržení určitých podmínek. Jednak měl být vypracován znalecký posudek, který by navrhl zabezpečení zdiva kostela před jeho znehodnocením $\mathrm{v}$ důsledku změny mnohasetletého mikroklimatu (poté, co se vyňatý fragment ocitne ve zcela novém prostředí). Další podmínkou bylo, aby projektová dokumentace řešila ochranu reliktů kostela po dobu realizace stavby. 


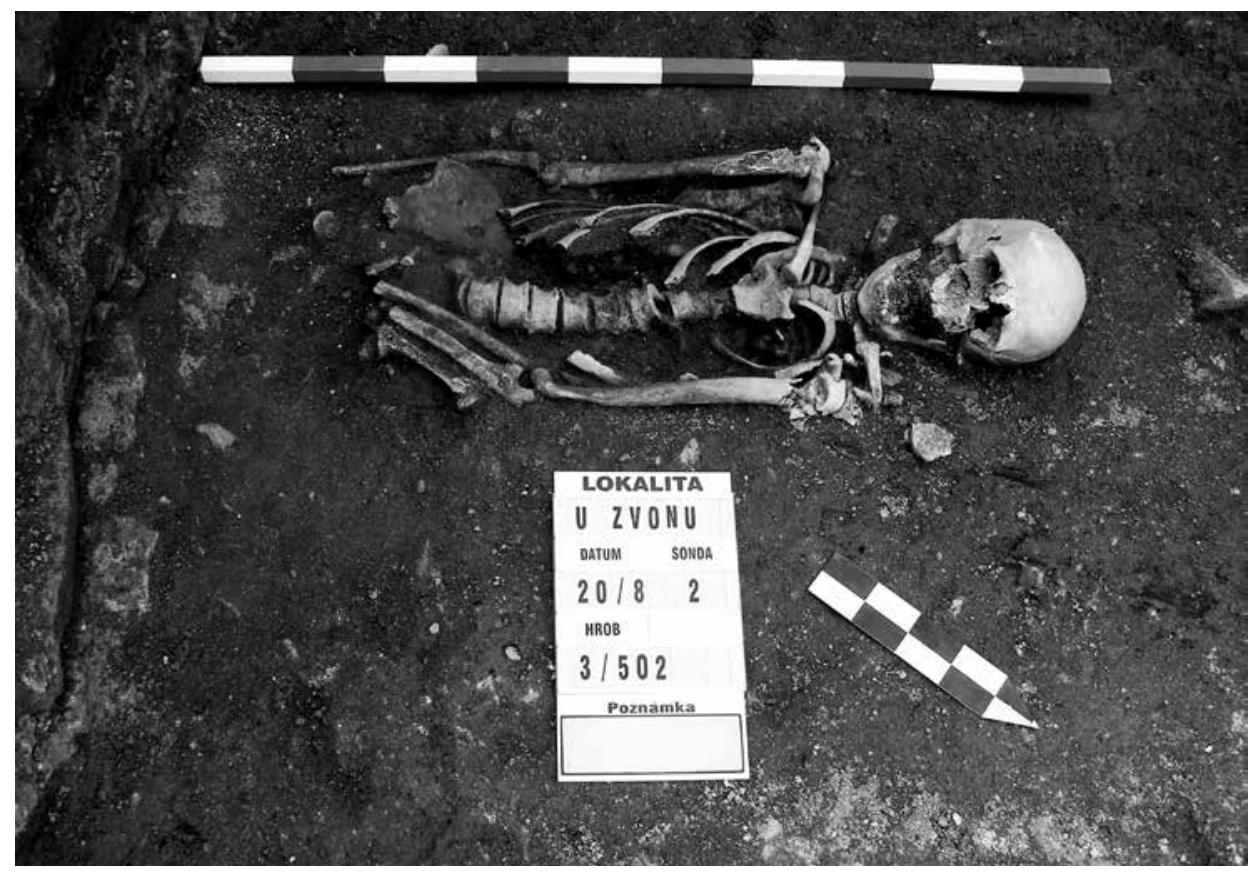

Obr. 16. Plzeň, kostel sv. Máří Magdaleny. Fotodokumentace hrobu 3/502. Foto O. Baier.

Abb. 16. Pilsen, Maria-Magdalenenkirche. Fotodokumentation von Grab 3/502. Foto O. Baier.

Ministerstvo kultury ČR zahájilo v únoru roku 2011 správní řízení ve věci návrhu na prohlášení archeologického nemovitého nálezu pozůstatků špitálního kostela sv. Máří Magdaleny za kulturní památku. Toto řízení bylo pravomocně ukončeno rozhodnutím MK ČR o prohlášení nálezu za kulturní památku ze dne 16. 1. 2012, přičemž 4. 2. 2012 nabylo právní moci (č. j. MK3526/2012OPP). Po dobu řízení, tedy přibližně jeden rok, nemohlo být na stavbu vydáno stavební povolení.

Prvně se k projektové dokumentaci novostavby ZČG pro vydání územního rozhodnutí mohl NPÚ, ÚOP v Plzni (dále jen NPÚ), oficiálně (dle § 14 zákona č. 20/1987 Sb.) vyjádřit až na základě žádosti Magistrátu města Plzně (MMP) ze dne 23. 4. 2012, tedy již v kontextu nových okolností.

Projektovou dokumentaci, která rozpracovávala řešení v intencích dohody z roku 2010, posuzoval NPÚ již jako zásah do kulturní památky a jako takový jej shledal nepřijatelným (č. j. NPÚ-341/34121/2012 ze dne 11. 5. 2012). Ve stručnosti bylo navrženo následující: Po vykopání zeminy měly být pod základovou spáru vyjímaného úseku zdiva kostela uloženy ocelové válcované profily, které by tvořily základní prvky nosného roštu pro vynesení zdiva kostela. Rošt by byl doplněn na celoplošnou podpůrnou konstrukci, na které by bylo možné staticky vynést (podepř́t a stabilizovat) celý blok zdiva. Zdivo kostela mělo být konzervováno v souběhu se zabedňováním a mechanickým zajištěním zdiva. Dále by bylo provedeno mimo vlastní zdivo kostela snížení na úroveň zhruba $1 \mathrm{~m}$ pod základovou spáru (z důvodu zhotovení navrženého souvrství). Po vybetonování železobetonové nosné desky by na ni byla podepřena ocelová konstrukce podporující zdivo kostela. V této fázi by bylo provedeno nové souvrství, rovněž pod vlastním historickým zdivem. Následně by pak byl celý prostor vyplněn směsí zeminy, jež by byla zhutněna, aby bylo zdivo chráněno proti možnému poškození vlivem následné stavební činnosti (Podaný 2011). 
Výše navržený způsob řešení představuje nevratný zásah do kulturní památky - oddělením části jižní stěny a presbyteria od zbylé části stavby (až po základovou spáru) by došlo de facto k jejímu fyzickému rozdělení. Nově vzniklý fragment zdiva by se v samostatné prostoře stal nepř́istupnou součástí novostavby. Oddělená část zdiva by se ocitla v jiném prostředí než dosud, což by urychlilo její degradaci; nové konstrukce oddělující vybrané úseky zdiva byly navíc navrženy v nevhodných místech - procházely přímo jedním z gotických opěrných pilírư presbyteria a jednou ze stěn sakristie, která je rovněž nedílnou součástí památky. Takovýto zásah vyhodnotil NPÚ jako neslučitelný s principy péče o kulturní památky.

Přesto vydal příslušný správní orgán památkové péče závazné stanovisko, v němž označil stavbu za př́pustnou, s podmínkou, že musí být dokončen archeologický průzkum kostela v celém půdorysném rozsahu a nálezové situace mají být plně zohledněny a zapracovány do dalšího stupně projektové dokumentace ke stavebnímu povolení (závazné stanovisko Magistrátu města Plzně č. j. MPP/094079/12 ze dne 15. 5. 2012). Hlavním argumentem k vydání opačného stanoviska oproti vyjádření NPÚ byly výsledky vyjednávání v roce 2010, kdy rovněž odborné složky památkové péče souhlasily s navrhovaným kompromisním řešením.

NPÚ podal následně, dne 31. 5. 2012 (č. j. NPÚ-341/44816/2012), na základě $§ 149$ odst. 5 zákona č. 500/2004 Sb., správního řádu, podnět k přezkoumání závazného stanoviska MMP, a to $\mathrm{z}$ důvodu nedostatků formálního charakteru a také $\mathrm{z}$ důvodu nepřezkoumatelnosti uvedené podmínky. Stanovisko bylo rovněž napadeno, že nehájí dostatečně zájmy památkové péče při ochraně kulturní památky. Bylo však zdůrazněno, že zájmy nové galerie a zájmy kulturní památky není nutné klást do protikladu, ale že jde čistě o nalezení technického řešení. Je podstatné dodat, že všechny tyto kroky již probíhaly v době, kdy byla výstavba ZČG z finančních důvodů odložena. Již tak nepř́ijemné pozice zúčastněných stran sporu naštěstí proto nebyly vyhroceny do krajnosti dalším tlakem ze strany investora a stavby. Na vedení přezkumného řízení byl relativně čas a rozhodnutím č. j. 593/SÚ/12-7 Odboru stavebního úřadu Krajského úřadu Karlovarského kraje $^{3}$ ze dne 19. 9. 2012 bylo nakonec závazné stanovisko MMP zrušeno.

Na obnoveném jednání, které se uskutečnilo dne 1. 10. $2012 \mathrm{v}$ užší skupině zainteresovaných stran (zástupce investora, NPÚ, MMP, ZČM a architekta), bylo dohodnuto, že bude vypracován nový návrh řešení v úzké spolupráci architektů s památkáři a archeology, který bude plně respektovat novou skutečnost, že nález pozůstatků kostela byl prohlášen kulturní památkou.

Následně vypracovaný nový návrh již plně fragmenty kostela respektuje, a to za cenu úprav interiéru prvního nadzemního podlaží nové budovy ZČG. Konkrétně je navrženo následující řešení: Základová konstrukce novostavby ZČG překlene korunu dochovaného zdiva zaniklého kostela - zdivo fragmentů kostela bude obsypáno inertním fixačním zásypem a bude chráněno dalšími izolačními vrstvami, aby bylo eliminováno případné sednutí objektu a hydroizolace. Nosná železobetonová deska novostavby bude dimenzována tak, aby překlenula fragmenty kostela bez negativního vlivu na dochované zdivo (Podaný-Koštál 2012). Po kladném vyjádření NPÚ (č. j. NPÚ-341/88309/2012 ze dne 26. 10. 2012) bylo na výše popsanou projektovou dokumentaci vydáno př́ípustné závazné stanovisko (č. j. MMP/238199/12 ze dne 29. 10. 2012).

\section{Závěr}

Porovnání výsledků záchranných archeologických výzkumů z let 2010-2014, stavebně historického průzkumu a výstupů výzkumu z roku 1946 prokázalo, že objekt kostela sv. Máŕí Magdaleny nelze posuzovat jako solitérní stavbu. Jeho propojení se špitálem není pouze symbolické, špitální budova poskytovala svatyni oporu a doplňovala vnitřní opěrný systém klenebních prrípor. Kostel a budova špitálu situovaná u jeho jižní stěny byly společně vystavěny po založení špitálu v roce 1320 .

\footnotetext{
3 Podnět k přezkoumání závazného stanoviska byl podán Krajskému úřadu Plzeňského kraje - usnesením MK ČR byl však této instituci odejmut a přikázán k vyřizení Krajskému úřadu Karlovarského kraje z důvodu existence pochybností o nepodjatosti (Krajský úř̌ad Plzeňského kraje je investorem nové budovy ZČG).
} 
Po husitských válkách se budova špitálu přesunula k západní stěně presbytáře. Tento přesun vyvolal stavební aktivity písemnými prameny doložené na přelomu 15. a 16. století.

Výrazná proměna podoby kostela nastala až s ukončením činnosti špitálu v této lokalitě na počátku třicetileté války. Kolem svatyně vznikl pohřební areál. S ním související nárůst terénu si vynutil zvýšení podlahy uvnitř kostela. To znamenalo zánik vnitřního opěrného systému a nutnost výstavby nového, situovaného na vnější straně stavby. Kostel byl prodloužen západním směrem. Tyto změny proběhly $\mathrm{v}$ rozmezí let 1648-1658. Před rokem 1703 byla přistavěna na jižní straně kostela sakristie. Nedlouho poté byl areál hřbitova s kostelem ohraničen zdí.

Současný stav reliktů kostela sv. Máří Magdaleny již neumožňuje plnohodnotnou rekonstrukci podoby této sakrální stavby. Situaci komplikuje také nemožnost dohledání nálezů z výzkumu v roce 1946 a přece jen určitá nedokonalost či tendenčnost výstupů tohoto výzkumu, odpovídající době vzniku. Přesto se podařilo vytvořit alespoň nástin stavebního vývoje špitální svatyně a chronologicky jej zařadit.

Na závěr je také třeba upozornit, že vstupní informace k reliktům kostela byly pro architektonickou soutěž i přes svou preciznost (dokumentace $\mathrm{k}$ archeologickému výzkumu z roku 1946) zásadním způsobem nedostatečné. Při pokusu o upřesnění polohopisného a výškopisného umístění reliktů kostela selhaly i nedestruktivní průzkumné metody; žádoucí poznatky byly zjištěny až při předstihovém záchranném archeologickém výzkumu, který proběhl po veřejné soutěži. Jak by se bývala řešila situace, kdyby zvítězil projekt, který počítal se zakomponováním pozůstatků kostela do interiéru novostavby ZČG (v soutěži se několik takových návrhů objevilo), když se po výzkumu ukázalo, že asi polovina zbytků kostela je mimo pozemky určené ke stavbě ZČG?!

V Plzni je v rámci veřejného prostranství prezentován jediný archeologický nález in situ tzv. Branka v dnešní ulici Bedřicha Smetany (pozůstatek jedné ze čtyř bran, tzv. Litické, městského opevnění).

$\mathrm{S}$ vědomím problematičnosti prezentace tzv. torzální architektury a zejména péče o ni (např. Waldmannová 2010) lze respektovat fakt, že v rámci interiéru vítězného návrhu nové budovy ZČG se s prezentací pozůstatků kostela sv. Máŕí Magdaleny nepočítá, i když zejména z technických důvodů týkajících se navrženého a výše popsaného způsobu založení novostavby. Přesto se $\mathrm{v}$ př́ípadě pozůstatků kostela sv. Máří Magdaleny nabízela možnost tzv. náznakové prezentace nálezu in situ (např. Merta-Peška-Tejkal 2010 nebo Čech 2010), a to v dlažbě chodníku podél severovýchodní stěny novostavby (obr. 2). Bohužel se tento návrh nepodařilo prosadit v rámci stavby „Rekonstrukce tramvajové trati Pražská - U Zvonu“, jejíž realizace byla shodou okolností ukončena na jaře 2015. Město Plzeň tak přišlo o jedinečnou př́iležitost vhodným způsobem prezentovat pozůstatky významné stavby, která se dobou vzniku vztahuje téměr̆ k vlastnímu založení Plzně a má i po svém zániku velmi zajímavé osudy.

\section{Prameny a literatura}

ANDERLE, J., 2015: Stavebně historický průzkum reliktů špitálu a kostela sv. Máŕí Magdaleny v Plzni. Rkp. ulož. v archivu odd. starších dějin Západočeského muzea v Plzni.

BĚLOHLÁVEK, M., 1997: Plzeňská předměstí. Plzeň.

BĚLOHLÁVEK, M. a kol., 1965: Dějiny Plzně I. Od počátků do roku 1788. Plzeň.

BYSTRICKÝ, V., 2014: Doba husitských válek (1419-1436). In: Dějiny města Plzně 1. Do roku 1788, 187-200. Plzeň.

ČECH, P., 2010: Stálé prezentace výsledků archeologických výzkumů v Žatci, ZPP 70, 198-200.

DUDKOVÁ, V.-ORNA, J.-NETOLICKÝ, P., 2014: Špitální areál sv. Máří Magdalény v Plzni - Das Spitalareal St. Maria Magdalena in Pilsen, AH 39, 221-239.

HAJŠMAN, J. -SOKOL, P., 2010: Toulky zaniklou Plzní. Plzeň.

HEJNIC, J.-POLÍVKA, M., 1987: Plzeň v husitské revoluci. Hilaria Litoměřického „Historie města Plzně“, její edice a historický rozbor. Praha. 
HISTORICKÝ ATLAS MĚST, 2009: Historický atlas měst České republiky, svazek č. 21 - Plzeň (Šimůnek, R., ed.). Plzeň - Praha.

KARLOVÁ, Š., 2008: Plzeňský špitál sv. Máří Magdaleny ve středověku (1320-1526). In: Scamma super Misam 1, 147-158. Plzeň.

KŘIVÁNEK, R., 2010: Plzeň (U Zvonu), okr. Plzeň-město. Závěrečná zpráva o geofyzikálním průzkumu. Rkp. ulož. v archivu odd. starších dějin Západočeského muzea v Plzni.

LÁBEK, L., 1947: Plzeňské Pompei, rkp. přednášky v Českém rozhlase z 3. 1. 1947, ulož. v Archivu města Plzně, Místopisná sbírka L. Lábka, složka Sv. Máří Magdaleny špitál.

MARTINOVSKÝ, I. a kol., 2004: Dějiny Plzně v datech od prvních stop osídlení až po současnost. Praha.

MENCL, V., 1946: Plzeň, výkop v kostelíku špitálu sv. Maří Magdaleny „U zvonu“. Zpráva o místní poradě 17. a 18. V., ulož. v archivu ARÚ AV ČR, Praha, v. v. i., čj. 2551/46.

- 1961: Plzeň. Sedm kapitol z její výtvarné minulosti. Plzeň.

MERGL, J., 1995: Plzeňské pohledy a veduty čtyř století 1500-1900. Plzeň.

MERTA, D.-PEŠKA, M.-TEJKAL, M., 2010: Městská památková rezervace Brno. Archeologie torzální architektury, její prezentace a 3D skenování, ZPP 70, 186-192.

Návrh akad. arch. Ladislava Kuby a Ing. M. A Tomáše Pilaře [on-line]. Dostupné z: http://www.zpc-galerie. cz/cs/vitezny-navrh-na-reseni-nove-budovy-zapadoceske-galerie-v-plzni-175.

NPÚ, ÚOP v Plzni, oddělení dokumentačních fondů a knihovny, Sbírka př́loh k Ústřednímu seznamu nemovitých kulturních památek, složka U Zvonu 4, 6, čp. 1.

NPÚ, ÚOP v Plzni, oddělení archeologie, složka Pozůstatky špitálního kostela sv. Máří Magdaleny, okr. Plzeň-město.

PODANÝ, Z., 2011: Návrh zajištění fragmentů kostela sv. Máří Magdaleny v lokalitě „U Zvonu“ v Plzni, vypracováno dne 7. 1. 2011 jako součást projektové dokumentace pro územní rízení „Nová budova Západočeské galerie v Plzni““ z listopadu 2010 (architekti: KUBA \& PILAŘ architekti s.r.o., Kopečná 58, 60200 Brno, autoři Ing. M. A. Tomáš Pilař, akad. arch. Ladislav Kuba, Ing. arch. Vít Košţál, inženýři: AED project, a. s., Pod Radnicí 1235/2A, 15000 Praha 5, autoři Ing. Aleš Marek, Ing. Zdeněk Podaný, Petr Homola). Kopie uložena ve spisovém archivu NPÚ, ÚOP v Plzni.

PODANÝ, Z.-KOŠŤÁL, V., 2012: Návrh zajištění fragmentů kostela sv. Máří Magdaleny v lokalitě „U Zvonu“ v Plzni, vypracováno dne 23. 10. 2012 jako součást projektové dokumentace pro územní rízení „Nová budova Západočeské galerie v Plzni“ z listopadu 2010 (architekti: KUBA \& PILAŘ architekti s.r.o., Kopečná 58, 60200 Brno, autoři Ing. M. A. Tomáš Pilař, akad. arch. Ladislav Kuba, Ing. arch. Vít Koštál, inženýři: AED project, a. s., Pod Radnicí 1235/2A, 15000 Praha 5, autoři Ing. Aleš Marek, Ing. Zdeněk Podaný, Petr Homola). Kopie uložena ve spisovém archivu NPÚ, ÚOP v Plzni.

SOKOL, P., 2013: Husité před branami. K topografii obležení Plzně v letech 1433 až 1434. In: Tenkrát na západě (Čech). Kapitoly z dějin kultury a každodennosti Plzně a Plzeňského kraje, 25-48. Plzeň.

STRNAD, J., 1891: Listář královského města Plzně a druhdy poddaných osad. Část I. Od r. 1300-1450. Plzeň.

- 1896: Klášter dominikánský v Plzni od svého založení až do zrušení (1300-1785). Plzeň.

- 1905: Listář královského města Plzně a druhdy poddaných osad. Část II. Od r. 1450-1526. Plzeň

ŠIROKÝ, R.-WASKOVÁ, M.-POSTRÁNECKÁ, K., 2007: Plzeň, lokalita U Zvonu. Stavebně historické a archeologické vyhodnocení území. Rkp. ulož. v archivu ZIP, o. p. s., čj. 433/07.

ŠPAČEK, R., 2010: Plzeň, Křižíkovy sady - U Zvonu. Průzkum podpovrchové situace. Geofyzikální měření - závěrečná zpráva. Rkp. ulož. v archivu odd. starších dějin Západočeského muzea v Plzni.

VAVŘINEC Z BŘEZOVÉ, 1979: Husitská kronika: píseň o vítězství u Domažlic (Bláhová, M., ed.). Praha.

WALDMANNOVÁ, M., 2010: Úpravna zlatých rud v Kašperských Horách aneb dvacet let života jedné památky, ZPP 70, 206-208.

WASKOVÁ, M.-ŠIROKÝ, R., 2007: Nástin topografie historického Skvrňanského předměstí v Plzni a otázka polohy nejstaršího židovského hřbitova - Ein Abriss der Topographie der historischen Skurnianer Vorstadt (Skvrňanské předměstí) in Pilsen (Plzeň) und die Frage der Lage des ältesten jüdischen Friedhofs. In: Nardi aristae. Sborník k 70. narozeninám Ivana Martinovského, 91-119. Ústí nad Labem. 


\section{Zusammenfassung}

\section{Torsale Architektur im historischen Stadtkern Pilsens am Beispiel der Spitalkirche HI. Maria Magdalena}

Die teilweise bereits 1946 untersuchten Überreste der Pilsener Spitalkirche H1. Maria Magdalena wurden 2010 im Zusammenhang mit dem Bauvorhaben des neuen Gebäudes der Westböhmischen Galerie erneut Gegenstand einer archäologischen Grabung. Der vorgelegte Beitrag präsentiert einerseits Teilergebnisse von der an den Überresten der Kirche erfolgten Grabung, d.h. eine teilweise Umbewertung der Mitte des 20. Jahrhunderts anhand der Grabung gezogenen Schlussfolgerungen, und andererseits dann auch eine zusammenfassende Darstellung der Ereignisse, die sich in Bezug auf dieses bedeutende Denkmal torsalen Charakters im Zusammenhang mit dem Bauvorhaben der neuen Westböhmischen Galerie zugetragen haben.

Durch einen Vergleich der Ergebnisse der in den Jahren 2010-2014 durchgeführten archäologischen Rettungsgrabung, der bauhistorischen Untersuchung und der Outputs der Grabung von 1946 wurde nachgewiesen, dass das Objekt der Pilsener Maria-Magdalenenkirche nicht als Solitärbau angesehen werden kann. Seine Verbindung zu einem Spital ist nicht nur symbolischer Natur. Das Spitalgebäude stellte für das Gotteshaus eine Stütze dar und ergänzte das innere Stützsystem der Gewölbedienste. Die Kirche und das an ihrer Südwand gelegene Spitalgebäude wurden nach Gründung des Spitals im Jahr 1320 gemeinsam aufgebaut.

Nach den Hussitenkriegen wurde das Spitalgebäude an die Westwand des Chorraums verlegt. Diese Verlagerung riefen die in schriftlichen Quellen von der Wende des 15. und 16. Jahrhunderts belegten Bauaktivitäten hervor. Eine deutliche Änderung ihres Aussehens widerfuhr der Kirche erst nachdem das Spital seinen Betrieb an diesem Standort zu Beginn des Dreißigjährigen Krieges eingestellt hatte. Um das Gotteshaus herum entstand ein Begräbnisareal. Der damit zusammenhängende Anstieg des Geländes machte eine Höherlegung des Fußbodens im Kircheninnern erforderlich. Das bedeutete das Ende des inneren Stützsystems und die Notwendigkeit, ein neues zu bauen, das sich an der Gebäudeaußenseite befand. Die Kirche wurde nach Westen hin verlängert. Diese Änderungen erfolgten in der Zeitspanne zwischen 1648-1658. Vor dem Jahr 1703 wurde an der Kirchensüdseite eine Sakristei angebaut. Nicht lange danach wurden Friedhofsareal und Kirche mit einer Mauer eingefriedet.

Der gegenwärtige Zustand der Relikte der Maria-Magdalenenkirche ermöglicht keine vollwertige Rekonstruktion des Aussehens dieses Sakralbaus. Die Situation gestaltet sich auch durch die Unmöglichkeit komplizierter, Funde von der Grabung aus dem Jahr 1946 zusammenzusuchen. Das gleiche gilt für den der damaligen Zeit entsprechenden und von daher in gewisser Weise nunmal unvollständigen bzw. tendenziösen Charakter der Outputs dieser Grabung. Trotzdem ist es gelungen, die bauliche Entwicklung der Spitalkirche zumindest zu skizzieren und chronologisch einzuordnen.

Erst durch die im Rahmen der archäologischen Rettungsgrabung 2010 erfolgten Freilegung der Überreste der Kirche wurde deutlich, dass die erhaltenen Relikte mit dem aus dem Architektenwettbewerb hervorgegangenen Siegerentwurf für das neue Gebäude der Westböhmischen Galerie in nicht unerheblichem Maße kollidieren. Aufgrund des hohen kulturhistorischen Wertes der Überreste der Maria-Magdalenenkirche wurde im September 2010 ein Antrag eingereicht, sie zum Kulturdenkmal erklären zu lassen, was dann im Februar 2012 auch erfolgte. Erst aufgrund dessen wurden die Baupläne so umgearbeitet, dass die Relikte dieses bedeutenden historischen Baus gänzlich erhalten bleiben können. Leider ist es nicht gelungen, eine Präsentationsform des Fundes durchzusetzen, noch nicht einmal eine andeutungsweise, wie etwa die Kennzeichnung des Grundrisses der Kirche bzw. ihres Teils in der neuen Pflasterung des Gehwegs neben dem künftigen Bau der Westböhmischen Galerie. 
Mgr. Veronika Dudková, Západočeské muzeum v Plzni, Kopeckého sady 2, 30100 Plzeň, Česká republika, vdudkova@zcm.cz

Mgr. Jiří Orna, Západočeské muzeum v Plzni, Kopeckého sady 2, 30100 Plzeň, Česká republika, jorna@zcm.cz

Mgr. Marcela Waldmannová, Národní památkový ústav, územní odborné pracoviště v Plzni, Prešovská 7 , 30637 Plzeň, Česká republika, waldmannova.marcela@npu.cz 
